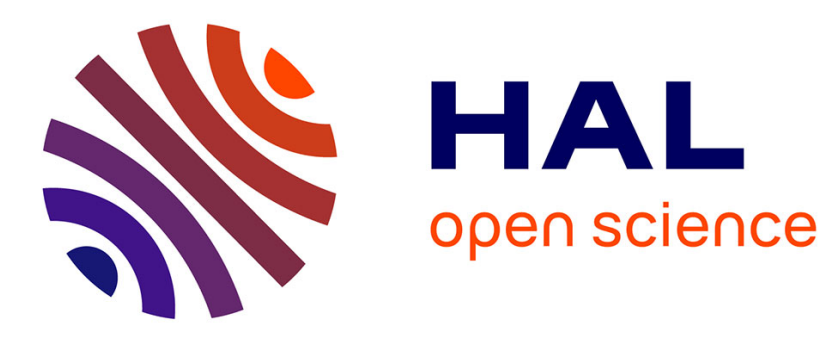

\title{
Catalytic wet air oxidation of aqueous solution of 2-chlorophenol over $\mathrm{Ru}$ /zirconia catalysts
}

Ning Li, Claude Descorme, Michèle Besson

\section{To cite this version:}

Ning Li, Claude Descorme, Michèle Besson. Catalytic wet air oxidation of aqueous solution of 2chlorophenol over Ru/zirconia catalysts. Applied Catalysis B: Environmental, 2007, 71, pp.262-270. 10.1016/j.apcatb.2006.09.009 . hal-00307354

\section{HAL Id: hal-00307354 \\ https://hal.science/hal-00307354}

Submitted on 14 Oct 2021

HAL is a multi-disciplinary open access archive for the deposit and dissemination of scientific research documents, whether they are published or not. The documents may come from teaching and research institutions in France or abroad, or from public or private research centers.
L'archive ouverte pluridisciplinaire HAL, est destinée au dépôt et à la diffusion de documents scientifiques de niveau recherche, publiés ou non, émanant des établissements d'enseignement et de recherche français ou étrangers, des laboratoires publics ou privés. 


\title{
Catalytic wet air oxidation of aqueous solution of 2-chlorophenol over Ru/zirconia catalysts
}

\author{
Ning Li, Claude Descorme* ${ }^{*}$, Michèle Besson \\ Institut de Recherches sur la Catalyse, CNRS, 2 Avenue Albert Einstein, 69626 Villeurbanne Cedex, France
}

$\mathrm{Ru}$ loaded zirconia catalysts $\left(\mathrm{Ru} / \mathrm{ZrO}_{2}\right)$ were found to be active in the catalytic wet air oxidation $(\mathrm{CWAO})$ of 2-chlorophenol (2-CP) at relatively mild temperature. To optimize the reaction conditions, the effects of different operating parameters, such as the rotation speed, the reaction temperature, the total pressure, the initial concentration and the $\mathrm{pH}$ of the initial 2- $\mathrm{CP}$ solution on the catalytic activity of 3 wt.\% Ru/ $\mathrm{ZrO}_{2}$ were evaluated. The activation energy for the $\mathrm{CWAO}$ of $2-\mathrm{CP}$ over $\mathrm{Ru} / \mathrm{ZrO}_{2}$ was calculated to be $36 \mathrm{~kJ}$ mol ${ }^{-1}$. The $2-\mathrm{CP}$ removal rate is zero order with respect to the initial 2-CP concentration. The CWAO of 2-CP changes from first order (oxygen diffusion control) to zero order (kinetic control) with respect to the oxygen partial pressure when the total pressure is higher than $4 \mathrm{MPa}$. The conversion of 2-CP increases with the $\mathrm{pH}$ of the initial 2-CP solution. The dechlorination reaction is promoted at higher $\mathrm{pH}$. However, too high $\mathrm{pH}$ limits the total mineralization of $2-\mathrm{CP}$ because the adsorption of the reaction intermediates is hindered. It was also confirmed that $\mathrm{Ru}(\mathrm{NO})\left(\mathrm{NO}_{3}\right)_{3}$ is better than $\mathrm{RuCl} l_{3}$ to act as a ruthenium precursor.

Keywords: Catalytic wet air oxidation (CWAO); Chlorophenol; Ru; Zirconia

\section{Introduction}

From the beginning of the 21 st century, with an increasing social and political concern on the environment, the removal of toxic organic compounds from aqueous wastewater has drawn a lot of attention [1-5]. Chlorophenols (CPs) are very important chemical compounds and intermediates in several chemical industries, such as the production of pesticides and dyes. Because most CPs are toxic, hardly biogradable and very difficult to remove from the environment, they constitute a particular group of priority toxic pollutants listed in both the US EPA Clean Water Act and the European Decision 2455/2001/ EC [1]. Therefore, to protect the environment, it is necessary to develop some highly efficient techniques for the treatment of such organic-contaminated wastewater. Among the different techniques applied for the elimination of CPs, such as the photocatalytic degradation [6,7], the supercritical water oxidation [8], the Fenton process [9], the ozonation [10], the microwave irradiation [11], the sonochemical degradation [12],

\footnotetext{
* Corresponding author. Tel.: +33 4724453 07; fax: +334 72445399 . E-mail address: claude.descorme@catalyse.cnrs.fr (C. Descorme).
}

etc., the wet air oxidation (WAO) is attracting more and more interest [13-20]. Using such a process, chlorinated organic contaminants might be totally mineralized by oxygen to $\mathrm{CO}_{2}$, $\mathrm{H}_{2} \mathrm{O}$ and $\mathrm{HCl}$, with relatively low energy consumption.

Generally, the WAO of organic compounds, in the absence of catalyst, was performed under high pressure (5-17.5 MPa) at high temperature $(473-598 \mathrm{~K})$ [21]. However, for the chlorinated organic compounds, serious corrosion problems might arise at such high temperature and pressure, due to the $\mathrm{HCl}$, which is produced during the decomposition process. Then, it is preferable to operate at temperature and pressure as low as possible, even though low temperature and pressure are unfavorable for the effective degradation of organic compounds in terms of reaction rate and reaction equilibrium. To solve this problem, some highly active catalysts must be found. In the past years, several catalysts have been developed for the catalytic wet air oxidation (CWAO) of chlorophenols. For example, Chang et al. [17] compared the activities of $\mathrm{CuSO}_{4}, \mathrm{MnO}_{2}$ and $\mathrm{Co}_{2} \mathrm{O}_{3}$ in the CWAO of 4-CP in the temperature range 423$473 \mathrm{~K}$. It was found that $\mathrm{CuSO}_{4}$ is the most effective catalyst and that alkaline conditions favor the degradation of 4-CP. Qin et al. [18] investigated the activities of Pt, $\mathrm{Pd}$ and $\mathrm{Ru}$ loaded alumina, ceria and activated carbon catalysts in the CWAO of 
4-CP at 453 K. Activated-carbon-supported catalysts were found to be the most active. Posada et al. [19] also studied the CWAO of 2-CP over $\mathrm{Cu}$ loaded ceria catalysts at $433 \mathrm{~K}$. It was suggested that the high activity of the copper-ceria catalysts is related to the modification of the structural and redox properties of the cerium oxide upon copper addition. However, the operating temperature for these catalysts was relatively high. Recently, Kojima et al. [20] found that $\mathrm{Ru}$ loaded $\mathrm{TiO}_{2}$ catalyst was active for the CWAO of 2-CP. Over this kind of catalyst, 2-CP could be completely removed at relatively mild temperature $(413 \mathrm{~K})$. Suarez-Ojeda et al. [16] used activated carbon as the catalyst for the CWAO of $2-\mathrm{CP}$ with a trickle bed system and got about 55\% 2-CP conversion and $50 \%$ TOC removal at $413 \mathrm{~K}$. However, it is still necessary to find some highly efficient catalysts operating at lower temperature. In previous works in our group, Ru loaded zirconia $\left(\mathrm{Ru} / \mathrm{ZrO}_{2}\right)$ catalysts were proved to be active for the wet air oxidation of Kraft bleaching plant effluents [22], phydroxybenzoic acid [23], acetic acid [24], succinic acid $[23,24]$ and $p$-coumaric acid [25]. In this work, we studied the catalytic performances of $\mathrm{Ru} / \mathrm{ZrO}_{2}$ for the CWAO of 2-CP. To optimize the catalyst performances, the effects of various parameters, such as the rotation speed, the ruthenium precursor, the reaction temperature, the total pressure, the initial concentration and the initial $\mathrm{pH}$ were investigated.

\section{Experimental}

\subsection{Catalyst preparation}

The $\mathrm{Ru}$ loaded zirconia catalyst was prepared as described previously [25]. The $\mathrm{ZrO}_{2}$ support was supplied by Melcat (XZ0 923/01, BET surface area $90 \mathrm{~m}^{2} \mathrm{~g}^{-1}$, particle size 15$20 \mu \mathrm{m})$. Ru was introduced by incipient wetness impregnation using aqueous solutions of $\mathrm{Ru}(\mathrm{NO})\left(\mathrm{NO}_{3}\right)_{3}$ (Alfa Aesar) or $\mathrm{RuCl}_{3}$ (Aldrich), which concentrations were accurately determined by ICP-AES before impregnation. After the impregnation, the preparation was dried for $24 \mathrm{~h}$ at room temperature, introduced in a quartz tube cell, reduced in flowing hydrogen $\left(15 \mathrm{~L} \mathrm{~h}^{-1}\right)$ at $573 \mathrm{~K}$ for $2 \mathrm{~h}$ (temperature ramp rate: $1 \mathrm{~K} \mathrm{~min}^{-1}$ ). After cooling down to room temperature under $\mathrm{H}_{2}$, the cell was purged with argon and the catalyst was further passivated at room temperature under flowing $1 \%$ $\mathrm{O}_{2} / \mathrm{N}_{2}\left(15 \mathrm{~L} \mathrm{~h}^{-1}\right)$ for $2 \mathrm{~h}$.

\subsection{Catalytic tests}

Experiments were carried out in a $300 \mathrm{~mL}$ autoclave made of Hastelloy C22 (model 4836, Parr Instrument Inc.). In a typical run, the autoclave was loaded with $150 \mathrm{~mL} 2-\mathrm{CP}$ aqueous solution $\left(2 \mathrm{~g} \mathrm{~L}^{-1}\right.$, i.e. initial total organic carbon (TOC), $1120 \mathrm{mg} \mathrm{L}^{-1}$ ) and $0.5 \mathrm{~g}$ catalyst. After the reactor was outgassed with argon, the mixture was heated to the reaction temperature under stirring over a period of ca. $0.5 \mathrm{~h}$. Then, the stirrer was stopped and the air was admitted into the reactor until the predefined pressure was reached. The reaction finally started when the stirring was switched on. This point was taken as "zero time" and one sample was withdrawn to measure the exact initial concentration of 2-CP. The 2-CP adsorption and/or dechlorination could be evaluated by comparison to the concentration of 2-CP introduced. Other liquid samples were periodically withdrawn from the reactor, centrifugated to remove any catalyst particle in the liquid sample and further analyzed.

The substrate and the reaction intermediates were analyzed using HPLC (Shimadzu) with a $250 \mathrm{~mm} \times 4.6 \mathrm{~mm} \mathrm{C18}$ reverse phase column (UP 5MM1-25QS, Interchim). The mobile phase was a mixture of $20 \mathrm{vol} \% \%$ methanol and 80 vol.\% water (flow rate, $1 \mathrm{~mL} \mathrm{~min}^{-1}$ ). The HPLC system was equipped with a UV-vis detector set at 210 and $281 \mathrm{~nm}$.

TOC in the liquid sample was measured with a Shimadzu 5050 TOC analyzer after subtraction of the inorganic carbon (IC) contribution to the total carbon (TC).

The $\mathrm{pH}$ of the liquid samples was measured using a $\mathrm{pH}$ meter (Radiometer Analytical PHM240).

\section{Results and discussion}

Mass transfers in liquid phase reactions are directly influenced by the efficiency of the stirring setup. Therefore, as a preliminary work, we investigated the effect of the rotation speed. Table 1 shows the initial rates for $2-\mathrm{CP}$ abatement over $3 \mathrm{wt} . \% \mathrm{Ru} / \mathrm{ZrO}_{2}$ catalyst, ex $\mathrm{RuCl}_{3}$, at different rotation speeds. These results indicate that $1000 \mathrm{rpm}$ is enough to ensure a vigorous and homogenous mixing of the reaction mixture with our experimental setup. Obviously, such an optimum cannot be translated directly to a different reactor and very different stiring conditions, as low as $150 \mathrm{rpm}$, are reported in the literature [20]. In the following, to make sure that the effect of the rotation speed can be excluded, that is no mass transfer limitation in the liquid phase, the rotation speed was set at $1300 \mathrm{rpm}$.

\subsection{Catalytic and non-catalytic wet air oxidation of 2-CP}

Fig. 1 shows the evolution as a function of time of the 2-CP conversion, the TOC removal value and the $\mathrm{pH}$ upon catalytic and non-catalytic WAO of a $2 \mathrm{~g} \mathrm{~L}^{-1} 2-\mathrm{CP}$ aqueous solution at $413 \mathrm{~K}$. In the absence of catalyst, the WAO of 2-CP is very slow. Even after $24 \mathrm{~h}$, the $2-\mathrm{CP}$ conversion $(34 \%)$ and the TOC removal $(29 \%)$ are still very low. This result is consistent with earlier results reported in the literature [20,26]. 2-CP is a relatively thermally stable molecule under the applied reaction conditions.

After introducing the $\mathrm{Ru} / \mathrm{ZrO}_{2}$ catalyst, ex $\mathrm{RuCl}_{3}$, the reaction was significantly accelerated. In fact, over this catalyst,

Table 1

Initial rates of 2-CP abatement at different rotation speeds

\begin{tabular}{ll}
\hline Rotation speed (rpm) & Initial rate of 2-CP $\left(\mathrm{mol}_{2-\mathrm{CP}} \mathrm{mol}_{\mathrm{Ru}}^{-1} \mathrm{~h}^{-1}\right)$ \\
\hline 700 & 6.8 \\
1000 & 8.7 \\
1300 & 8.5 \\
1500 & 8.9 \\
\hline
\end{tabular}

$0.5 \mathrm{~g} 3$ wt. \% Ru/ZrO${ }_{2}\left(\mathrm{RuCl}_{3}\right)$ catalyst, $413 \mathrm{~K}, 5 \mathrm{MPa}, 1300 \mathrm{rpm}$ and [2$\mathrm{CP}]_{0}=2 \mathrm{~g} \mathrm{~L}^{-1}$. 

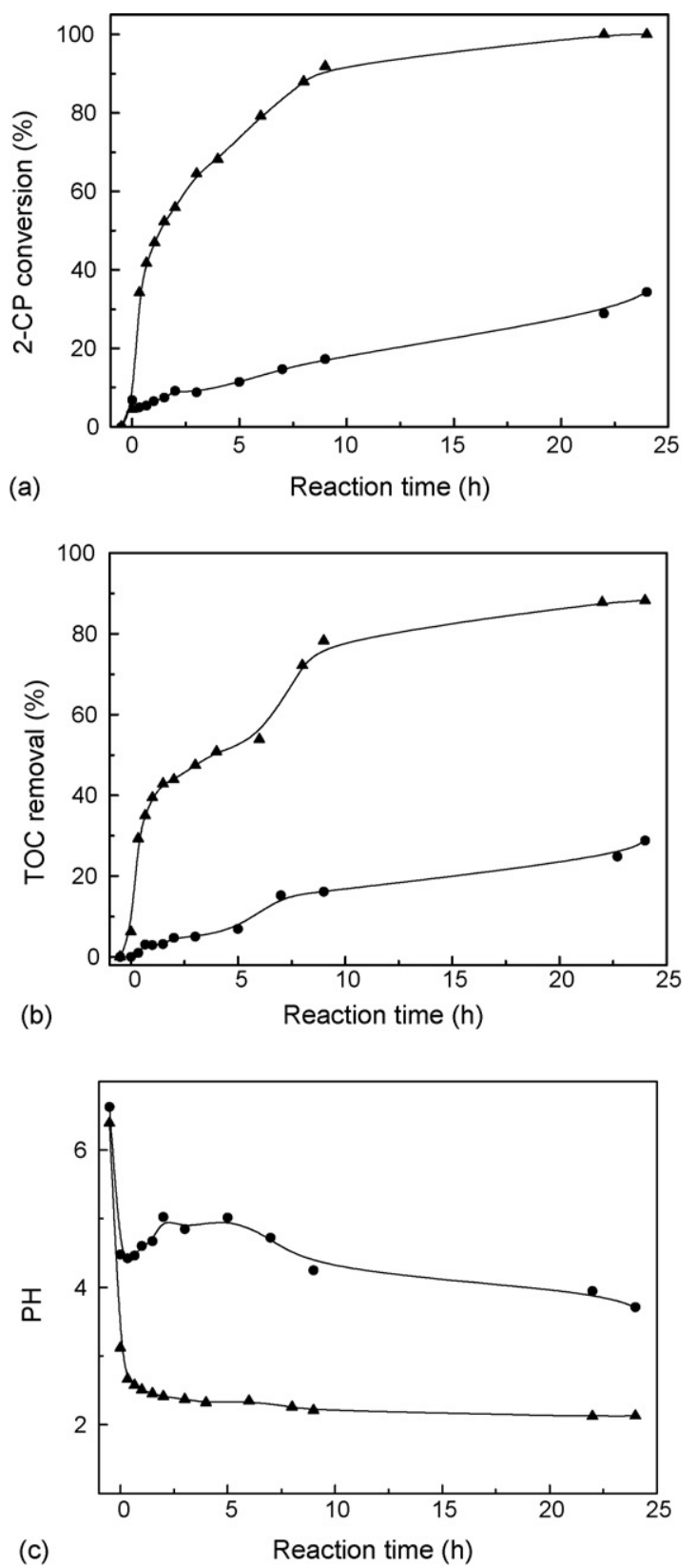

Fig. 1. Evolution of the 2-CP conversion (a), the TOC removal (b) and the $\mathrm{pH}$ (c) in the wet air oxidation (WAO) of 2-CP without catalyst (-) or over $3 \mathrm{wt} . \%$ $\mathrm{Ru} / \mathrm{ZrO}_{2}\left(\mathrm{RuCl}_{3}\right)(\mathbf{\Delta})[0$ or $0.5 \mathrm{~g}$ catalyst, $413 \mathrm{~K}, 5 \mathrm{MPa}, 1300 \mathrm{rpm}$, [2$\left.\mathrm{CP}]_{0}=2 \mathrm{~g} \mathrm{~L}^{-1}\right]$.

2-CP was completely converted after $24 \mathrm{~h}$ and TOC abatement reached $88 \%$ by that time. From these results, one can conclude that $\mathrm{Ru} / \mathrm{ZrO}_{2}$ is an effective catalyst for the CWAO of 2-CP.

Furthermore, one can notice that the 2-CP conversion at zero time is not 0 . The partial dechlorination or the adsorption of 2-CP to the catalyst surface might be responsible for that. This hypothesis was further confirmed by looking at the TOC results. In fact, the TOC abatement at zero time is about 0 in the absence of any catalyst, while, it is $6 \%$ over $\mathrm{Ru} / \mathrm{ZrO}_{2}$, which value is almost the same as the observed 2-CP conversion (4\%). Therefore, we think the TOC removal at zero time $\left(\mathrm{TOC}_{0}\right)$ can be used to quantify the initial adsorption of 2-CP on the catalyst surface.
The initial $\mathrm{pH}$ of the 2-CP solution was about 6.3. Upon the WAO reaction, the $\mathrm{pH}$ of the solution decreases (Fig. 1). This decrease is more obvious in the presence of the catalyst. Such an increase of the acidity is directly related to the degradation of 2-CP and the formation of small organic acids as well as $\mathrm{HCl}$ (2-CP dechlorination) [20]. In fact, a deeper oxidation is observed in the presence of $\mathrm{Ru} / \mathrm{ZrO}_{2}$. As a result, smaller (and stronger) acids are generated and a lower $\mathrm{pH}$ is measured at the end of the reaction. From the analysis, small chain carboxylic acids such as acetic acid, chloroacetic acid and succinic acid could be identified. Consequently, although a significant degassing of the $\mathrm{CO}_{2}$ dissolved in water at high pressure occurs upon sampling, a rapid measure of the final $\mathrm{pH}$ might already give some qualitative information about the degradation degree of the 2-CP molecule.

As reported in the literature $[16,20]$, we also confirmed the existence in the liquid samples of trace amounts of aromatic intermediates, such as catechol, chlorohydroquinone, hydroquinone, chloro- $p$-benzoquinone and benzoquinone.

Finally, after calculating the selectivity of the reaction by dividing the TOC removal by the 2-CP conversion, we found that the selectivity is higher than $74 \%$ all along the $24 \mathrm{~h}$ reaction, indicating that $\mathrm{Ru} / \mathrm{ZrO}_{2}$ is so efficient that most of the 2-CP was directly mineralized to $\mathrm{CO}_{2}, \mathrm{H}_{2} \mathrm{O}$ and $\mathrm{HCl}$. In fact, after $24 \mathrm{~h}, 2-\mathrm{CP}$ is nearly completely mineralized (88\%) under such conditions.

\subsection{Effect of experimental parameters on the catalytic performances of $\mathrm{Ru} / \mathrm{ZrO} \mathrm{O}_{2}$}

\subsubsection{Ru precursor}

We investigated the effect of the nature of the Ru precursor $\left(\mathrm{RuCl}_{3}\right.$ versus $\left.\mathrm{Ru}(\mathrm{NO})\left(\mathrm{NO}_{3}\right)_{3}\right)$ on the catalytic performances of 3 wt. $\% \mathrm{Ru} / \mathrm{ZrO}_{2}$ catalysts. The results are presented in Fig. 2. As demonstrated earlier by Besson et al. in the CWAO of $p$ hydroxybenzoic acid [27], we observed that the catalyst prepared from $\mathrm{Ru}(\mathrm{NO})\left(\mathrm{NO}_{3}\right)_{3}$ as the Ru precursor, was slightly more active, even though higher initial rates could be measured when $\mathrm{RuCl}_{3}$ was used as a precursor (which is the reason why we measured the mass transfer limitation over the $\mathrm{Ru} / \mathrm{ZrO}_{2}$ ex $\mathrm{RuCl}_{3}$ ). In fact, over the $3 \mathrm{wt} . \% \mathrm{Ru} / \mathrm{ZrO}_{2}$ catalyst prepared with $\mathrm{Ru}(\mathrm{NO})\left(\mathrm{NO}_{3}\right)_{3}$, almost complete 2-CP conversion and higher TOC removal could be obtained at shorter time of reaction. Therefore, we think $\mathrm{Ru}(\mathrm{NO})\left(\mathrm{NO}_{3}\right)_{3}$ is better than $\mathrm{RuCl}_{3}$ to act as a $\mathrm{Ru}$ precursor for the preparation of $\mathrm{Ru} / \mathrm{ZrO}_{2}$ catalysts. Besson et al. [27] have already characterized the Ru dispersion of identical $\mathrm{Ru} / \mathrm{ZrO}_{2}$ catalysts prepared from different metal precursor. According to their report, the average $\mathrm{Ru}$ particle size in the catalysts prepared from $\mathrm{RuCl}_{3}$ and $\mathrm{Ru}(\mathrm{NO})\left(\mathrm{NO}_{3}\right)_{3}$ were respectively 2.9 and $2.5 \mathrm{~nm}$. Apart the metal distribution at the oxide surface (accessibility) that might be different depending on the metal precursor which is used [27], one could also imagine that the presence of some residual chlorine at the catalyst surface may hinder the reaction. In fact, when chlorinated metal precursors are used for the preparation, some chlorine sits at the metal-support interface [28,29]. It has been demonstrated earlier that such chlorine species would 

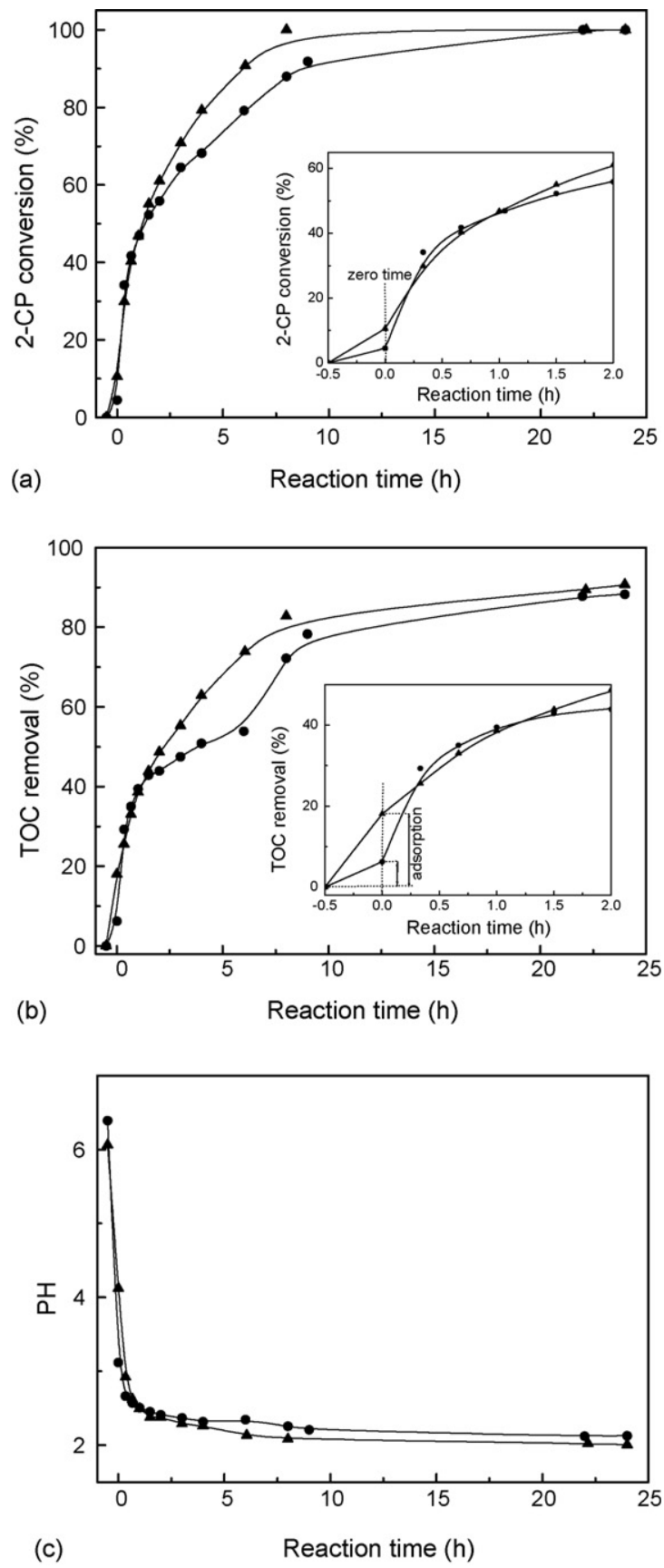

Fig. 2. Evolution of the 2-CP conversion (a), the TOC removal (b) and the $\mathrm{pH}$ (c) in the catalytic wet air oxidation (CWAO) of 2-CP over $3 \mathrm{wt} . \% \mathrm{Ru} / \mathrm{ZrO}_{2}$ prepared from $\mathrm{RuCl}_{3}(\boldsymbol{O})$ or from $\mathrm{Ru}(\mathrm{NO})\left(\mathrm{NO}_{3}\right)_{3}(\boldsymbol{\Delta})$ as the ruthenium precursor [0.5 g catalyst, $413 \mathrm{~K}, 5 \mathrm{MPa}, 1300 \mathrm{rpm},[2-\mathrm{CP}]_{0}=2 \mathrm{~g} \mathrm{~L}^{-1}$ ].

prevent the oxygen diffusion from the oxide to the metal particle and vice-versa [30]. Consequently, if the oxygen mobility at the catalyst surface is somehow blocked when chlorinated precursors are used, the reactivity of such catalysts would directly be negatively impacted. There is also another possibility, that is, a $\mathrm{Cl}$ migration towards specific sites where they have a more severe poisoning effect. Furthermore, it can be noticed from Fig. $2 b$ that the TOC removal at zero time over 3 wt. $\% \mathrm{Ru} / \mathrm{ZrO}_{2}$ ex $\mathrm{Ru}(\mathrm{NO})\left(\mathrm{NO}_{3}\right)_{3}(18 \%)$ is much higher than that over 3 wt. $\% \mathrm{Ru} / \mathrm{ZrO}_{2}$ ex $\mathrm{RuCl}_{3}(6 \%)$. On the bare support, the TOC removal at zero time was $15 \%$. Such an observation would also suggest that 2-CP adsorption is somehow hindered in the presence of chlorine on the catalyst surface. In the following work, $\mathrm{Ru}(\mathrm{NO})\left(\mathrm{NO}_{3}\right)_{3}$ only is used for the catalyst preparation.

Finally, one might note that when $\mathrm{RuCl}_{3}$ was used, the initial $\mathrm{pH}(t=0)$ of the solution (3.1) is lower than the one measured when $\mathrm{Ru}(\mathrm{NO})\left(\mathrm{NO}_{3}\right)_{3}$ is used (4.1). This result might be explained by the presence of some residual $\mathrm{Cl}^{-}$on the catalyst surface which might dissolve into the solution as hydrochloric acid (hydrolysis reaction). Later, as the reaction proceeds, more acids (essentially more $\mathrm{HCl}$ ) would be generated over the 3 wt. $\% \mathrm{Ru} / \mathrm{ZrO}{ }_{2}$ catalyst prepared with $\mathrm{Ru}(\mathrm{NO})\left(\mathrm{NO}_{3}\right)_{3}$ which is more active and $\mathrm{pH}$ would reach the same value as for the catalyst prepared with $\mathrm{RuCl}_{3}$. Of course, another explanation would be that zero time is not rigorously the same for the two experiments. At the very beginning of the reaction the $\mathrm{pH}$ decreases sharply in a very short period of time. Any difference for $t=0$ might explain this initial difference in $\mathrm{pH}$. The first sample $(t=0)$ might have been withdrawn a fraction of a minute later in the case of $\mathrm{Ru} / \mathrm{ZrO}_{2}$ ex $\mathrm{RuCl}_{3}$ and the reaction might have already proceed. Furthermore, as stated above, when chlorinated metal precursors are used for the preparation of supported metal catalysts, chlorine essentially sits at the metal-support interface, even after reduction of the catalyst under hydrogen [28,29]. Such strongly adsorbed chlorine species would probably hardly dissolve into the solution to form $\mathrm{HCl}$ upon reaction and the second explanation might be preferred.

\subsubsection{Reaction temperature}

The influence of the reaction temperature was studied in the range $403-433 \mathrm{~K}$. Fig. 3 shows the evolution of the 2-CP conversion, the TOC removal and the $\mathrm{pH}$ upon reaction over a 3 wt. \% $\mathrm{Ru} / \mathrm{ZrO}_{2}$ ex $\mathrm{Ru}(\mathrm{NO})\left(\mathrm{NO}_{3}\right)_{3}$ catalyst at different temperatures. Just as we anticipated, the 2-CP conversion and the TOC removal increased with temperature. As a result, the $\mathrm{pH}$ of the solution also decreased faster when increasing the temperature. As a conclusion, higher temperatures are favorable for the CWAO of 2-CP. However, higher temperatures practically translate into higher operating costs and severe corrosion problems due to the presence of $\mathrm{HCl}$ generated during the reaction. Additionally, from a fundamental point of view, one has to make sure that the reaction is operated under chemical control, that is, not too fast. In order to observe the effects of other operating parameters, the reaction should not be too fast either. Taking into consideration the above-mentioned multisided reasons, we considered $413 \mathrm{~K}$ as the optimum temperature for the study of the CWAO of 2-CP over $\mathrm{Ru} / \mathrm{ZrO}_{2}$ catalysts. Fig. $3 \mathrm{~b}$ shows that TOC removal values at zero time and different temperatures are almost the same $(\sim 18 \%)$. 2-CP is strongly adsorbed on the catalyst surface, and the reaction temperature has no effect on the initial adsorption of 2-CP within the investigated temperature range.

Finally, from the Arrhenius plot ( $\ln r_{0(2-\mathrm{CP})}$ versus $\left.1 / T\right)$ for the evolution of the initial rate of 2-CP removal as a function of temperature, the apparent activation energy for the CWAO of 

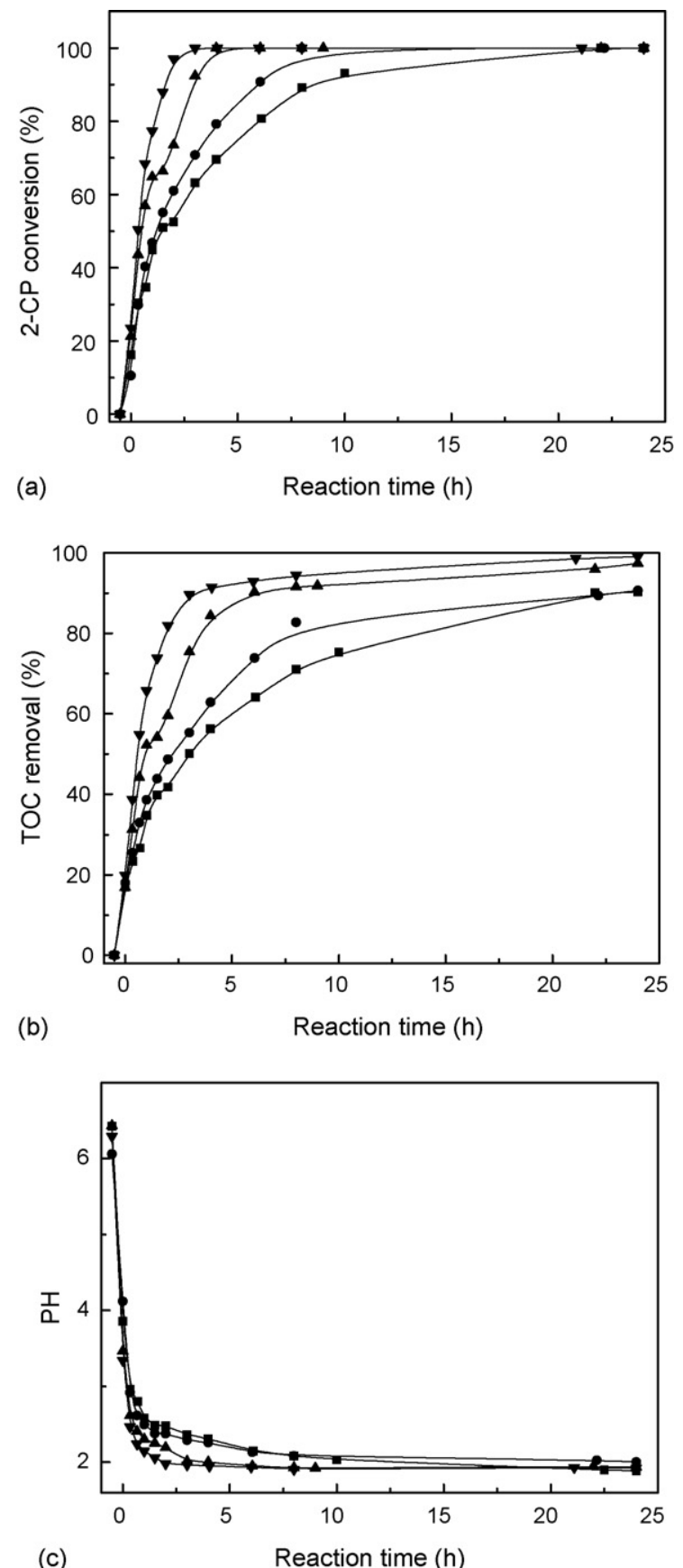

(c)

Reaction time (h)

Fig. 3. Evolution of the 2-CP conversion (a), the TOC removal (b) and the $\mathrm{pH}$ (c) in the CWAO of 2-CP over $3 \mathrm{wt} . \% \mathrm{Ru} / \mathrm{ZrO}_{2}\left(\mathrm{Ru}(\mathrm{NO})\left(\mathrm{NO}_{3}\right)_{3}\right)$ at $403 \mathrm{~K}(\mathbf{\square})$, $413 \mathrm{~K}(\boldsymbol{\bullet}), 423 \mathrm{~K}(\boldsymbol{\Delta})$ and $433 \mathrm{~K}(\boldsymbol{\nabla})$ [0.5 g catalyst, $5 \mathrm{MPa}, 1300 \mathrm{rpm}$, [2$\left.\mathrm{CP}]_{0}=2 \mathrm{~g} \mathrm{~L}^{-1}\right]$.

2-CP was calculated to be $36 \mathrm{~kJ} \mathrm{~mol}^{-1}$ ( $r$ parameter: -0.9981). Joglekar et al. [26] reported that the activation energy for the WAO of 2-CP is $138 \mathrm{~kJ} \mathrm{~mol}^{-1}$ during the induction period and $145 \mathrm{~kJ} \mathrm{~mol}^{-1}$ upon steady state operation. So, in the presence of the $\mathrm{Ru} / \mathrm{ZrO}_{2}$ catalyst, the activation energy for the elimination of 2-CP is clearly decreased and the reason for the promoting effect of $\mathrm{Ru} / \mathrm{ZrO}_{2}$ is clearly identified. It was previously reported that the activation energy is $34 \mathrm{~kJ} \mathrm{~mol}^{-1}$ for the CWAO of phenol over Pt-Ru/C [31]. Such values are strictly comparable. Not surprisingly, activation energies for the elimination of the smaller organic acids, which are refractory to the oxidation, are higher. It was calculated that the activation energy is $125 \mathrm{~kJ} \mathrm{~mol}^{-1}$ for the CWAO of succinic acid over Ru/ $\mathrm{TiO}_{2}$ [32] and $101 \mathrm{~kJ} \mathrm{~mol}^{-1}$ for the CWAO of acetic acid over $\mathrm{Ru} / \mathrm{C}$ [33].

\subsubsection{Total pressure}

It has been found earlier that the partial pressure of $\mathrm{O}_{2}$ has some impact on both the conversion and the mineralization of phenol and succinic acid upon CWAO [32,34,35]. This effect might be related to the availability of oxygen to the active site. The partial pressure of oxygen in the gas phase will partly determine the concentration in oxygen in the liquid phase. According to the Henry's law, the concentration of $\mathrm{O}_{2}$ dissolved in the liquid phase is proportional to the partial pressure of $\mathrm{O}_{2}$ in the gas phase. Furthermore, let us note that the total pressure in the gas phase results from the sum of the initial Ar atmosphere after the reactor has been purged at room temperature, the autogenous pressure which appears upon heating (essentially water vapor), and the air pressure balance. Taking into account that, at $413 \mathrm{~K}$, the saturated water vapor pressure is $0.36 \mathrm{MPa}$ and that the argon pressure was $0.14 \mathrm{MPa}$, when the total pressure is $5 \mathrm{MPa}$, the partial pressure of air and oxygen are 4.5 and $0.9 \mathrm{MPa}$, respectively, the oxygen solubility is ca. $0.26 \mathrm{~g} \mathrm{~L}^{-1}$ [17].

Additionally, it was calculated from reaction (1) that the stoichiometric amount of oxygen, required for the complete oxidation of 2-CP to $\mathrm{CO}_{2}$ and $\mathrm{H}_{2} \mathrm{O}$ under our reaction conditions, corresponds to $0.27 \mathrm{MPa}$, that is the air pressure should be higher than $1.35 \mathrm{MPa}$ :

$\mathrm{C}_{6} \mathrm{H}_{5} \mathrm{Cl}+6.5 \mathrm{O}_{2}=6 \mathrm{CO}_{2}+2 \mathrm{H}_{2} \mathrm{O}+\mathrm{HCl}$

Consequently, the minimum total pressure was set at $2 \mathrm{MPa}$ to avoid any parallel reactions, such as the polymerization.

We investigated the effect of the total pressure (between 2 and $6 \mathrm{MPa}$ ) using $3 \mathrm{wt} . \% \mathrm{Ru} / \mathrm{ZrO}{ }_{2}$, ex Ru(NO)(NO$)_{3}$ at $413 \mathrm{~K}$. As shown in Fig. 4a, the conversion of 2-CP improved when the total pressure increased. This effect was only noticeable when the total pressure increased from 2 to $4 \mathrm{MPa}$, while the difference between 4 and $6 \mathrm{MPa}$ was somewhat insignificant. The oxygen diffusion to the catalyst surface is not limiting anymore for the reaction and, above $4 \mathrm{MPa}$, the CWAO of 2-CP transforms from oxygen diffusion-controlled to kineticcontrolled. This behavior is clearly exemplified in Fig. 5 (initial rate for 2-CP abatement versus total pressure and oxygen partial pressure). When total pressure is below $4 \mathrm{MPa}$, the initial rate for the 2-CP elimination is first order with respect to the oxygen pressure. Above this limit, the conversion of 2-CP is zero order with respect to the oxygen pressure. These results are similar to what has been found by Joglekar et al. [26] in the WAO of phenol and 2-CP (in the absence of any catalyst) and Chang et al. [35] in the CWAO of phenol over $\mathrm{CeO}_{2} / \gamma-\mathrm{Al}_{2} \mathrm{O}_{3}$ catalysts. When we increased the total pressure from 2 to $6 \mathrm{MPa}$, the TOC removal values at zero time and different oxygen partial pressure were almost the same (14-18\%). This result suggests that the partial pressure of oxygen has no effect on the adsorption of 2-CP on the catalyst surface. 

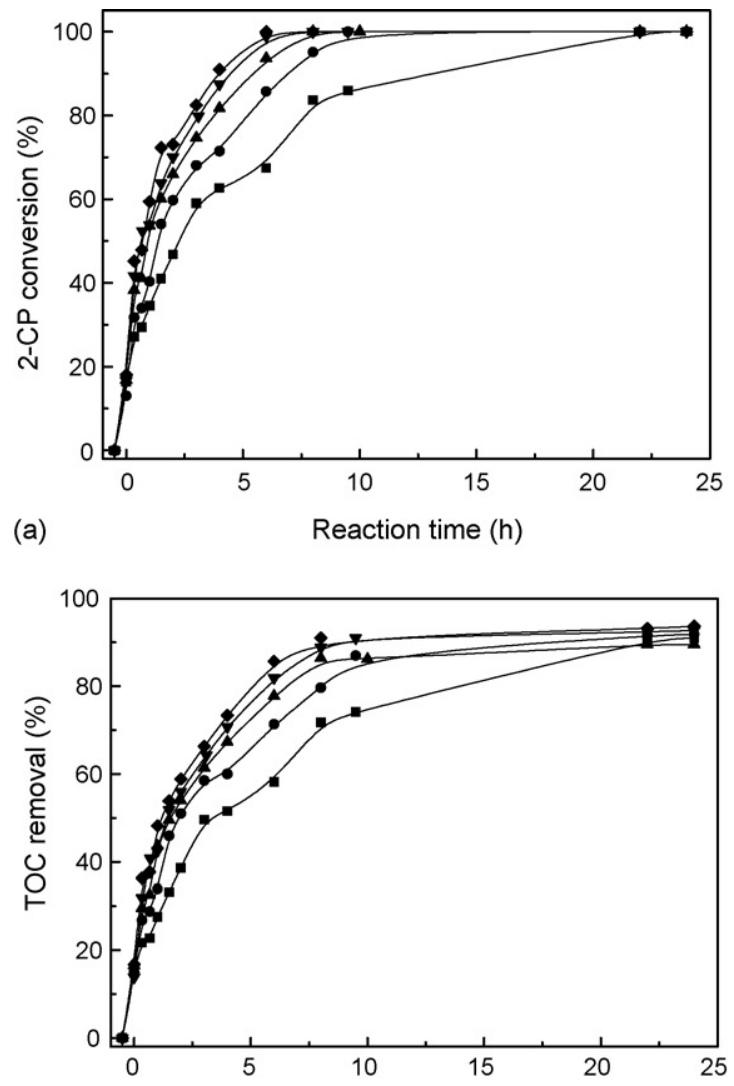

(b)

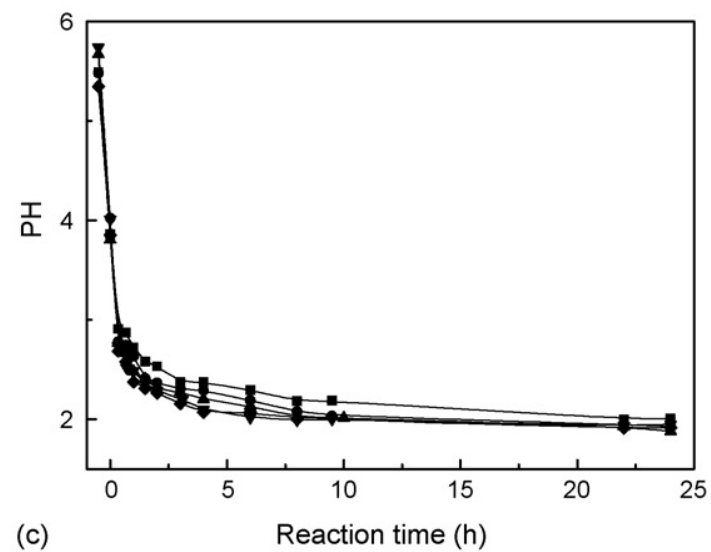

Fig. 4. Evolution of the 2-CP conversion (a), the TOC removal (b) and the $\mathrm{pH}$ (c) in the CWAO of $2-\mathrm{CP}$ over $3 \mathrm{wt} . \% \mathrm{Ru} / \mathrm{ZrO}_{2}\left(\mathrm{Ru}(\mathrm{NO})\left(\mathrm{NO}_{3}\right)_{3}\right)$ at $2 \mathrm{MPa}(\boldsymbol{\square})$, $3 \mathrm{MPa}(\bullet), 4 \mathrm{MPa}(\boldsymbol{\nabla}), 5 \mathrm{MPa}(\boldsymbol{\Delta})$ and $6 \mathrm{MPa}(\diamond)[0.5 \mathrm{~g}$ catalyst, $413 \mathrm{~K}$, $\left.1300 \mathrm{rpm},[2-\mathrm{CP}]_{0}=2 \mathrm{~g} \mathrm{~L}^{-1}\right]$.

The total pressure had a greater effect on the TOC removal than on the 2-CP conversion at least at short contact time. Within the investigated pressure range $(2-6 \mathrm{MPa})$, the TOC abatement increased continuously with the total pressure (Fig. 4b). These results are analogous with what has been found in the CWAO of phenol $[34,35]$ and can be explained by the fact that the total mineralization of $2-\mathrm{CP}$ needs more oxygen.

\subsubsection{Initial 2-CP concentration}

Fig. 6 shows the result for the CWAO of 2-CP solutions $(0.2-$ $2 \mathrm{~g} \mathrm{~L}^{-1}$ ) over 3 wt. $\% \mathrm{Ru} / \mathrm{ZrO}_{2}$, ex $\mathrm{Ru}(\mathrm{NO})\left(\mathrm{NO}_{3}\right)_{3}$, at $413 \mathrm{~K}$

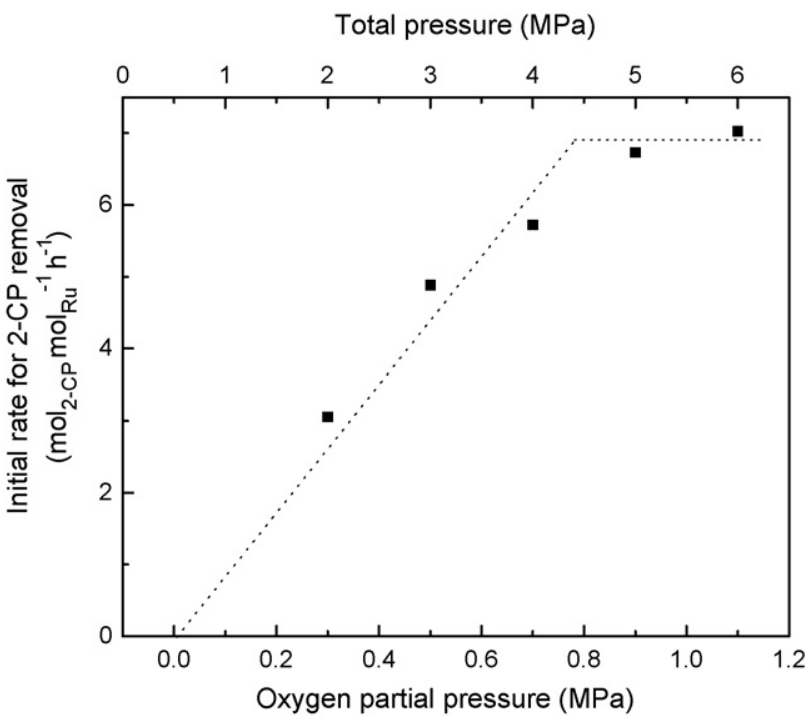

Fig. 5. Evolution of the initial rate of 2-CP conversion as a function of the total pressure $\left[0.5 \mathrm{~g} 3 \mathrm{wt} . \% \mathrm{Ru} / \mathrm{ZrO}_{2}\left(\mathrm{Ru}(\mathrm{NO})\left(\mathrm{NO}_{3}\right)_{3}\right), 413 \mathrm{~K}, P: 2-6 \mathrm{MPa}\right.$, $\left.1300 \mathrm{rpm},[2-\mathrm{CP}]_{0}=2 \mathrm{~g} \mathrm{~L}^{-1}\right]$.

and $5 \mathrm{MPa}$ total pressure. The initial rate for the 2-CP elimination is about constant (Table 2). There is only one singular point, when the concentration of $2-\mathrm{CP}$ is as low as $0.2 \mathrm{~g} \mathrm{~L}^{-1}$. In this case, a much lower initial rate of $2-\mathrm{CP}$ abatement was measured. However, with such a low amount of 2-CP in the solution, the fraction of the 2-CP molecules which are initially adsorbed on the catalyst surface might become predominant and the initial rate of reaction cannot be accurately determined. Furthermore, as far as HPLC is used for the liquid phase analysis, some inaccuracies in the concentration determination might have a strong impact. These results suggest that the reaction order is zero with respect to the initial 2-CP concentration and can be explained by the saturation of the active sites on the $\mathrm{Ru} / \mathrm{ZrO}_{2}$ surface with 2-CP molecules.

From Fig. 7, it can be seen that the initial 2-CP adsorption over $\mathrm{Ru} / \mathrm{ZrO}_{2}$ is almost proportional to the initial 2-CP concentration and then levels off when the initial 2-CP concentration is higher than $1 \mathrm{~g} \mathrm{~L}^{-1}$. The maximum 2-CP adsorption capacity for the catalyst is about $60 \mathrm{mg}_{2-\mathrm{CP}} \mathrm{g}_{\text {catalyst }}^{-1}$ and a Langmuir-Hinshelwood type of adsorption isotherm is observed.

Furthermore, it is worthy noticing that the evolution of $\mathrm{pH}$ as a function of time (Fig. 6c) is also peculiar when the initial 2-CP

Table 2

Initial rates of 2-CP abatement of 2-CP solutions with different initial concentrations

\begin{tabular}{ll}
\hline $\begin{array}{l}\text { Concentration of 2-CP } \\
\text { solution }\left(\mathrm{g} \mathrm{L}^{-1}\right)\end{array}$ & $\begin{array}{l}\text { Initial rate of 2-CP } \\
\text { abatement }\left(\mathrm{mol}_{2-\mathrm{CP}} \mathrm{mol}_{\mathrm{Ru}}^{-1} \mathrm{~h}^{-1}\right)\end{array}$ \\
\hline 0.2 & 2.8 \\
0.5 & 6.4 \\
1 & 6.3 \\
2 & 6.7 \\
\hline
\end{tabular}

$0.5 \mathrm{~g} 3$ wt. $\% \mathrm{Ru} / \mathrm{ZrO}_{2}\left(\mathrm{Ru}(\mathrm{NO})\left(\mathrm{NO}_{3}\right)_{3}\right)$ catalyst, $413 \mathrm{~K}, 5 \mathrm{MPa}$ and $1300 \mathrm{rpm}$. 

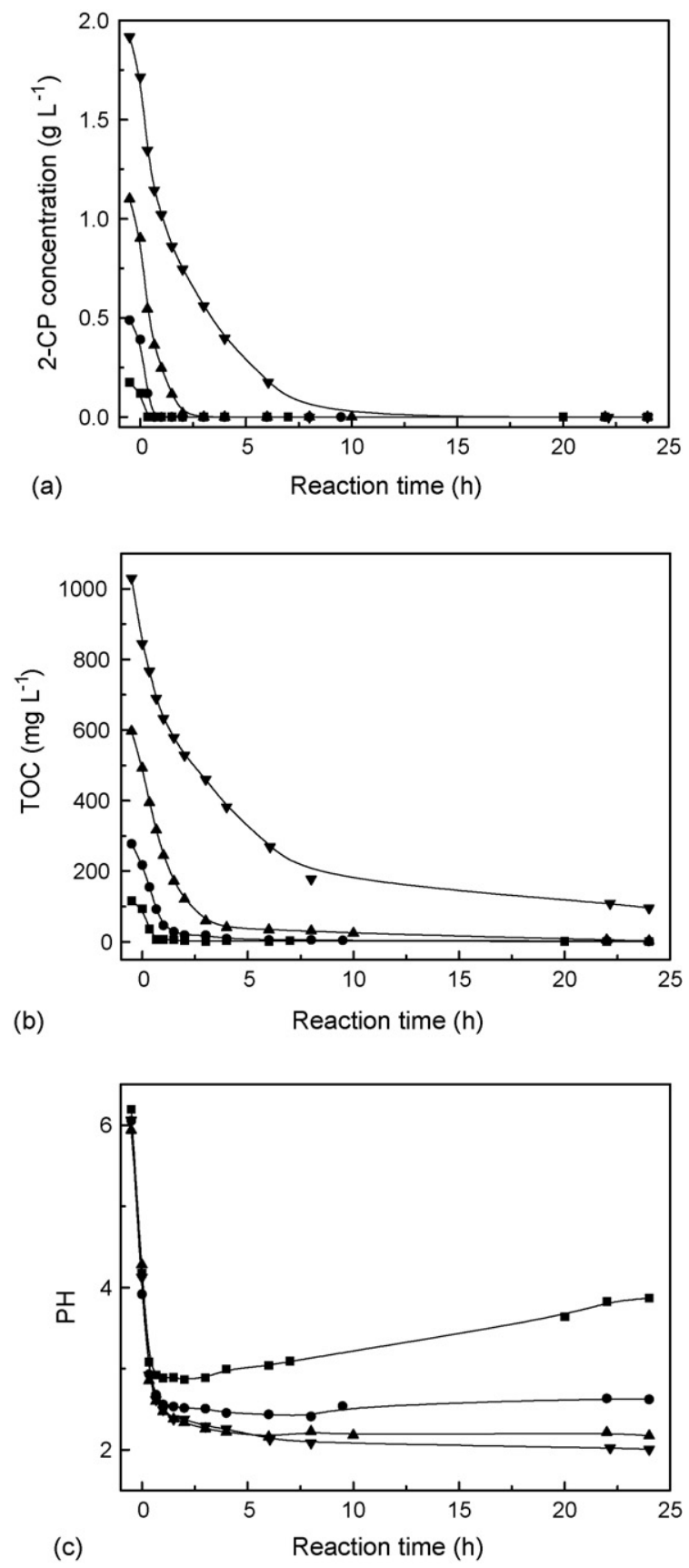

Fig. 6. Evolution of the 2-CP concentration (a), the TOC (b) and the $\mathrm{pH}$ (c) in the CWAO of $2-\mathrm{CP}$ over $3 \mathrm{wt} \% \mathrm{Ru} / \mathrm{ZrO}_{2}\left(\mathrm{Ru}(\mathrm{NO})\left(\mathrm{NO}_{3}\right)_{3}\right)[0.5 \mathrm{~g}$ catalyst, $413 \mathrm{~K}, 5 \mathrm{MPa}, 1300 \mathrm{rpm},[2-\mathrm{CP}]_{0}=0.2 \mathrm{~g} \mathrm{~L}^{-1}(\mathbf{\square}), 0.5 \mathrm{~g} \mathrm{~L}^{-1}(\mathbf{O}), 1 \mathrm{~g} \mathrm{~L}^{-1}$ $\left.(\mathbf{\Delta}), 2 \mathrm{~g} \mathrm{~L}^{-1}(\boldsymbol{\nabla})\right]$.

concentration is $0.2 \mathrm{~g} \mathrm{~L}^{-1}$. Because the initial 2-CP concentration is very low, less $\mathrm{HCl}$ is generated after the total mineralization of 2-CP and the minimum $\mathrm{pH}$ is higher. Furthermore, at the end of the reaction, the $\mathrm{pH}$ of the solution increased. This result is consistent with the higher TOC removal observed in this case and can be explained by the total mineralization of the 2-CP molecules to $\mathrm{CO}_{2}$ and $\mathrm{H}_{2} \mathrm{O}$. These two phenomena explain the different trends observed in the $\mathrm{pH}$ evolution.

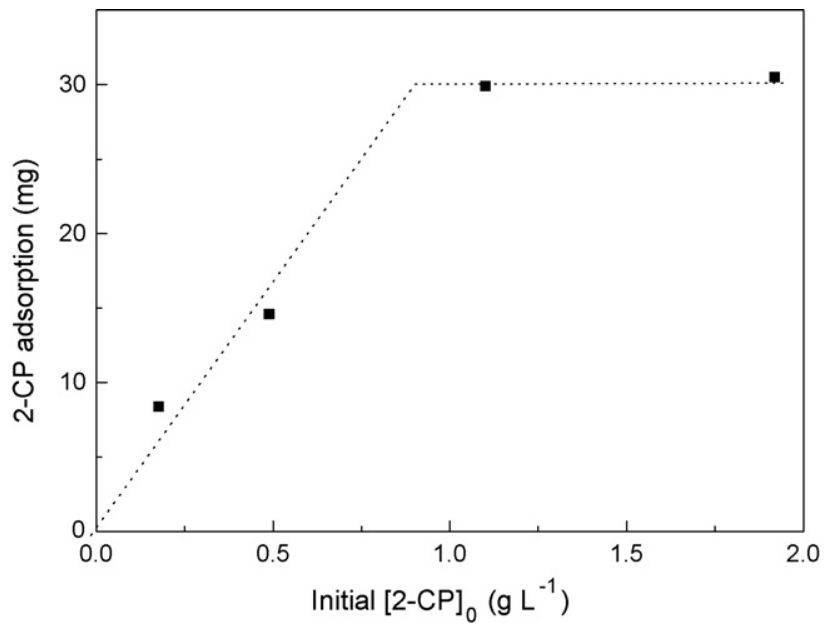

Fig. 7. Evolution of the 2-CP adsorption as a function of the initial 2-CP concentration $\left[0.5 \mathrm{~g} 3 \mathrm{wt} . \% \mathrm{Ru} / \mathrm{ZrO}_{2} \quad\left(\mathrm{Ru}(\mathrm{NO})\left(\mathrm{NO}_{3}\right)_{3}\right), 413 \mathrm{~K}, 5 \mathrm{MPa}\right.$, $\left.1300 \mathrm{rpm},[2-\mathrm{CP}]_{0}=0.2-2 \mathrm{~g} \mathrm{~L}^{-1}\right]$.

\subsubsection{Initial $\mathrm{pH}$ value of the 2-CP solution}

The effect of $\mathrm{pH}$ on the efficiency and selectivity of the oxidation process was studied with the objective to find the optimum conditions for the complete transformation of 2-CP to harmless products $\left(\mathrm{H}_{2} \mathrm{O}\right.$ and $\left.\mathrm{CO}_{2}\right)$. Experiments were carried out with a $2 \mathrm{~g} \mathrm{~L}^{-1} 2$-CP solution with initial $\mathrm{pH}$ in the range 212. Reactions were performed using 3 wt. $\% \mathrm{Ru} / \mathrm{ZrO}_{2}$, ex $\mathrm{Ru}(\mathrm{NO})\left(\mathrm{NO}_{3}\right)_{3}$, at $413 \mathrm{~K}$ and under $5 \mathrm{MPa}$ total pressure. Either $\mathrm{H}_{3} \mathrm{PO}_{4}$ or $\mathrm{NaOH}$ were used to adjust the initial $\mathrm{pH}$ to the desired value.

Fig. 8 shows the results. It is clear that both the 2-CP conversion and the TOC removal increased when increasing the initial $\mathrm{pH}$ from 2 to 10 . Then, increasing the $\mathrm{pH}$ from 10 to 12 , the initial $2-\mathrm{CP}$ conversion rate went on increasing but the TOC abatement stayed almost constant. These results are similar to what has been found by Kojima et al. on $\mathrm{Ru} / \mathrm{TiO}_{2}$ [20] and can be explained by the conflict that somehow exists between the dechlorination reaction of the 2-CP molecule and the surface adsorption properties of the $\mathrm{Ru} / \mathrm{ZrO}_{2}$ catalyst. On one hand, as found by Kojima et al. [20] in the WAO of 2$\mathrm{CP}$, higher initial $\mathrm{pH}$ can prompt the conversion of $2-\mathrm{CP}$ because the dechlorination reaction is accelerated. This may be the reason why 2-CP conversion and TOC removal increased when the initial $\mathrm{pH}$ increased from 2 to 10 . On the other hand, too high $\mathrm{pH}$ will lead to the negative charging of the zirconia surface. Such phenomenon may hinder the adsorption of some negatively charged chemical species because of the electrostatic barrier and therefore limit the subsequent total oxidation of the intermediates. To check this, we measured the $\mathrm{pH}$ at the point of zero charge $\left(\mathrm{pH}_{\mathrm{PZC}}\right)$ for the $\mathrm{ZrO}_{2}$ support using the method already described by Brunelle [36]. The $\mathrm{pH}_{\mathrm{PZC}}$ for the $\mathrm{ZrO}_{2}$ support we used in this study was measured as 6.1. The $\mathrm{p} K_{\mathrm{a}}$ of $2-\mathrm{CP}$, acetic acid, chloroacetic acid and succinic acid are 8.5, 4.8, 2.9 and 4.2, respectively. From Fig. 8c, one can see that the $\mathrm{pH}$ of the solution, when the initial $\mathrm{pH}$ is 12.1 , is about higher than 6.1 all along the reaction. This situation is different from what is 

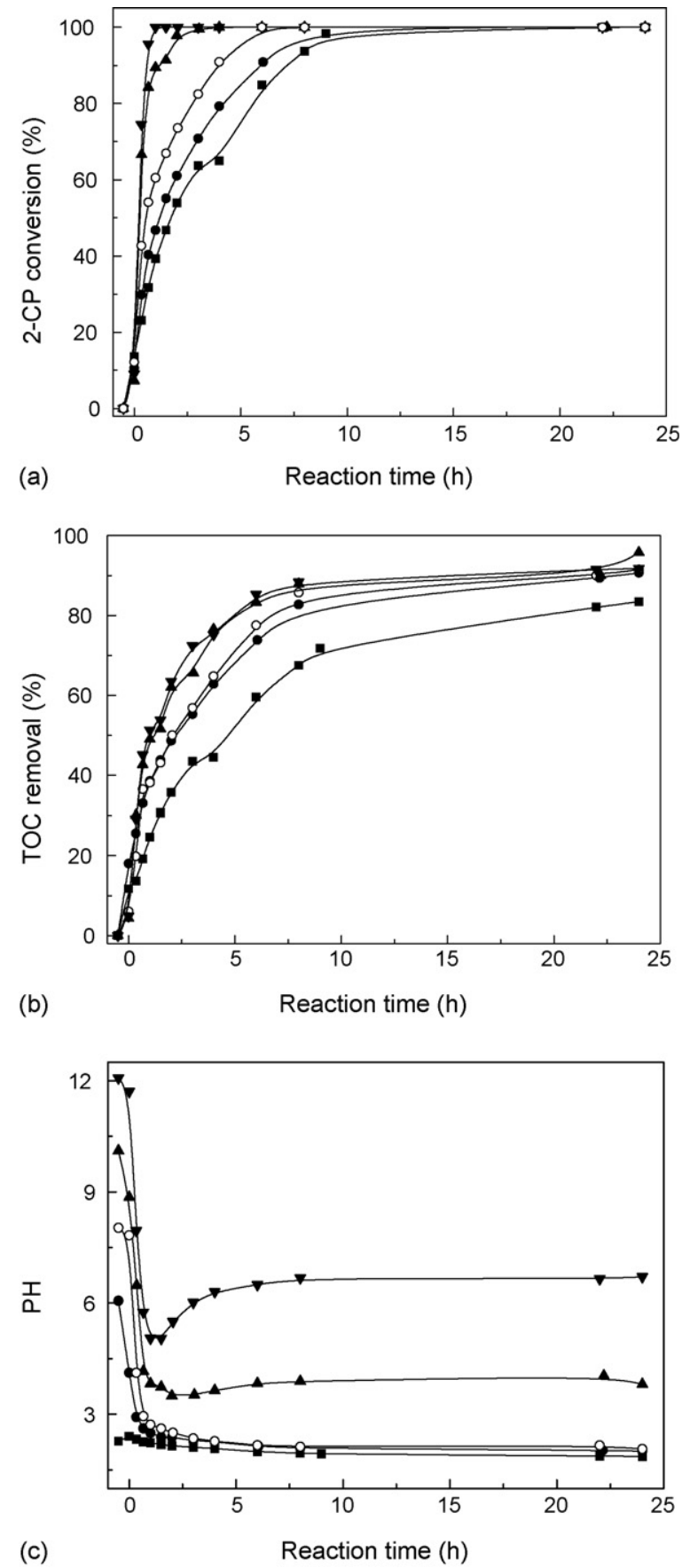

Fig. 8. Evolution of the 2-CP conversion (a), the TOC removal (b) and the $\mathrm{pH}$ (c) in the CWAO of 2-CP over 3 wt. $\% \mathrm{Ru} / \mathrm{ZrO}_{2}\left(\mathrm{Ru}(\mathrm{NO})\left(\mathrm{NO}_{3}\right)_{3}\right)[0.5 \mathrm{~g}$ catalyst, $413 \mathrm{~K}, 5 \mathrm{MPa}, 1300 \mathrm{rpm},[2-\mathrm{CP}]_{0}=2 \mathrm{~g} \mathrm{~L}^{-1}$, initial pH $2.3(\mathbf{\square}), 6.1(\bullet), 8.0$ (O), $10.1(\mathbf{\Delta}), 12.1(\boldsymbol{\nabla})]$.

observed at lower initial $\mathrm{pH}$. Consequently, the surface of $\mathrm{ZrO}_{2}$ is almost constantly negatively charged. Furthermore, most of the organic acids exist in the form of anions at such $\mathrm{pH}$. Then, it is difficult for the acids to adsorb on the catalyst surface and the TOC abatement is limited. This is the reason why there are different trends between the 2-CP conversion and the TOC removal after increasing of initial $\mathrm{pH}$ of the 2$\mathrm{CP}$ solution from 10 to 12 . Consequently, $\mathrm{pH} 10$ might be considered as the optimum.
The TOC removal values at zero time when initial $\mathrm{pH} 2.3$, $6.1,8.0,10.1$, and 12.1 were $12,18,6,4$, and $5 \%$, respectively. From these results, we can see that the adsorption of 2-CP increased with $\mathrm{pH}$ at the beginning, reached a maximum when initial $\mathrm{pH}$ is 6.1 , then decreased with increasing $\mathrm{pH}$. This is comprehensible because when the initial $\mathrm{pH}$ is 6.1 , the surface of the catalyst $\left(\mathrm{pH}_{\mathrm{PZC}} 6.1\right)$ is neutral, and there is no electrostatic barrier to prevent the adsorption of the reaction intermediates.

Finally, one can notice that, when the initial $\mathrm{pH}$ is greater than 10, the $\mathrm{pH}$ of the solution first decreases and then increases at the end of the reaction. This result is similar to what we observed at very low 2-CP initial concentration and can be explained by the deeper oxidation of the organic acids to $\mathrm{CO}_{2}$ and $\mathrm{H}_{2} \mathrm{O}$. This trend for the evolution of the $\mathrm{pH}$ as a function of time is even more pronounced when the initial $\mathrm{pH}$ is 12.1. However, when the initial $\mathrm{pH}$ of the solution is 10.1 and 12.1 , the minimum $\mathrm{pH}$ upon reaction is 3.5 and 5, respectively, and the final $\mathrm{pH}$ of the solution is about 4.0 and 6.7 , respectively. Such differences might derive from different reaction routes and explain the differences in the catalyst performances (2-CP conversion, TOC abatement, etc.).

\subsubsection{Leaching of $R u$}

The $\mathrm{Ru}$ concentration in the liquid phase after $24 \mathrm{~h}$ reaction was repeatedly measured by ICP-AES. As earlier reported in the CWAO on the $\mathrm{Ru} / \mathrm{ZrO}_{2}$ catalyst $[22,25]$, no Ru could be detected. The $\mathrm{Ru}$ concentration in the solution was systematically lower than $0.5 \mathrm{ppm}$ which is the detection limit of the ICP-AES equipement we used.

\section{Conclusions}

It was demonstrated that $\mathrm{Ru} / \mathrm{ZrO}_{2}$ is an efficient catalyst for the CWAO of 2-CP. Over this type of catalyst and high 2-CP conversion and TOC removal can be reached at mild reaction temperature $(413 \mathrm{~K})$ and moderate pressure $(5 \mathrm{MPa})$. The efficiency of $\mathrm{Ru} / \mathrm{ZrO}_{2}$ is very high, only little amount of intermediates were observed during the reaction. $\mathrm{Ru}(\mathrm{NO})\left(\mathrm{NO}_{3}\right)_{3}$ appeared as the optimum precursor for the preparation of $\mathrm{Ru} / \mathrm{ZrO}_{2}$ catalysts, because 2-CP adsorption is favored in the absence of any chlorine on the catalyst surface. The activation energy for this reaction was calculated to be $36 \mathrm{~kJ} \mathrm{~mol}^{-1}$. The CWAO of 2-CP is first order in oxygen when the total pressure is lower than $4 \mathrm{MPa}$. Above $4 \mathrm{MPa}$, the reaction shifts from oxygen diffusion controlled to kinetic controlled, and the CWAO of 2-CP changes from first order to zero order with respect to the oxygen partial pressure. Additionally, the 2-CP removal rate is zero order with respect to the initial 2-CP concentration due to the saturation of the $\mathrm{Ru} /$ $\mathrm{ZrO}_{2}$ surface with 2-CP molecules. Alkaline conditions favor the conversion of 2-CP by accelerating the dechlorination reaction. However, too high $\mathrm{pH}$ also hinder the total mineralization of 2-CP by preventing the adsorption of the intermediates on the catalyst surface (electrostatic barrier). Initial $\mathrm{pH} 10$ should be preferred. 


\section{Acknowledgements}

CNRS post-doctoral fellowship to support Dr. Ning Li's research work in France is gratefully acknowledged. The authors also thank G. Aubert for his precious technical help.

\section{References}

[1] M. Pera-Titus, V. García-Molina, M.A. Baños, J. Giménez, S. Esplugas, Appl. Catal. B: Environ. 47 (2004) 219-256.

[2] T.E. Agustina, H.M. Ang, V.K. Vareek, J. Photochem. Photobiol. C: Photochem. Rev. 6 (2005) 264-273.

[3] S.K. Bhargava, J. Tardio, J. Prasad, K. Fö1ger, D.B. Akolekar, S.C. Grocott, Ind. Eng. Chem. Res. 45 (2006) 1221-1258.

[4] A. Pintar, M. Besson, P. Gallezot, Appl. Catal. B: Environ. 31 (2001) 275290.

[5] A. Pintar, G. Berčič, M. Besson, P. Gallezot, Appl. Catal. B: Environ. 47 (2004) 143-152.

[6] J.M. Herrmann, J. Matos, J. Disdier, C. Guillard, J. Laine, S. Malato, J. Blanco, Catal. Today 54 (1999) 255-265.

[7] M. Czaplicka, J. Hazard. Mater. B 134 (2006) 45-59.

[8] G. Lee, T. Nunoura, Y. Matsumura, K. Yamamoto, J. Supercrit. Fluids 24 (2002) 239-250.

[9] M.C. Lu, J.N. Chen, H.H. Huang, Chemosphere 46 (2000) 131-136.

[10] C.H. Ni, J.N. Chen, Water Sci. Technol. 43 (2001) 213-220.

[11] A. Zhihui, Y. Peng, L. Xiaohua, Chemosphere 60 (2005) 824-827.

[12] H. Hao, Y. Chen, M. Wu, H. Wang, Y. Yin, Z. Lu, Ultrason. Sonochem. 11 (2004) 43-46.

[13] V.S. Mishra, V.V. Mahajani, J.B. Joshi, Ind. Eng. Chem. Res. 34 (1995) $2-$ 48.

[14] Y.I. Matatov-Meytal, M. Sheintuch, Ind. Eng. Chem. Res. 37 (1998) 309326.
[15] M. Stoyanova, S.G. Chirstoskova, M. Gergieva, Appl. Catal. A: Gen. 248 (2003) 249-259.

[16] M.E. Suarez-Ojeda, F. Stüber, A. Fortuny, A. Fabregat, J. Carrera, J. Font, Appl. Catal. B: Environ. 58 (2005) 105-114.

[17] C.J. Chang, S.-S. Li, C.-M. Ko, J. Chem. Technol. Biotechnol. 64 (1995) 245-252.

[18] J. Qin, Q. Zhang, K.T. Chuang, Appl. Catal. B: Environ. 29 (2001) 115123.

[19] D. Posada, P. Betancourt, F. Liendo, J.L. Brito, Catal. Lett. 106 (2006) 8188.

[20] Y. Kojima, T. Fukuta, T. Yamada, M.S. Onyango, E.C. Bernardo, H. Matsuda, K. Yagishita, Water Res. 39 (2005) 29-36.

[21] H. Debellefontaine, J.N. Foussard, Waste Manage. 20 (2000) 15-25.

[22] A. Pintar, M. Besson, P. Gallezot, Appl. Catal. B: Environ. 30 (2001) 123139.

[23] M. Besson, P. Gallezot, Top. Catal. 33 (2005) 101-108.

[24] N. Perkas, D. Pham Minh, P. Gallezot, A. Gedanken, M. Besson, Appl. Catal. B: Environ. 59 (2005) 121-130.

[25] D. Pham Minh, P. Gallezot, M. Besson, Appl. Catal. B: Environ. 63 (2006) 68-75.

[26] H.S. Joglekar, S.D. Samant, J.B. Joshi, Water Res. 25 (1991) 135-145.

[27] D. Pham Minh, P. Gallezot, M. Besson, Appl. Catal. B: Environ., in press.

[28] D.I. Kondarides, X.E. Verykios, J. Catal. 174 (1998) 52-64.

[29] A. Wootsch, C. Descorme, D. Duprez, J. Catal. 225 (2004) 259-266.

[30] C. Descorme, D. Duprez, Appl. Catal. A: Gen. 202 (2000) 231-241.

[31] J.E. Atwater, J.R. Akse, J.A. McKinnis, J.O. Thompson, Chemosphere 34 (1997) 203-212.

[32] J.C. Béziat, M. Besson, P. Gallezot, S. Durécu, J. Catal. 182 (1999) 129-135.

[33] P. Gallezot, S. Chaumet, A. Perrard, P. Isnard, J. Catal. 168 (1997) 104 109.

[34] S.S. Lin, D.J. Chang, C.H. Wang, C.C. Chen, Water Res. 37 (2003) $793-$ 800.

[35] L. Chang, I.P. Chen, S.S. Lin, Chemosphere 58 (2005) 485-492.

[36] J.P. Brunelle, Pure Appl. Chem. 50 (1978) 1211-1229. 